\title{
Polygonum multiflorum Thunb. Hot Water Extract Reverses High-Fat Diet-Induced Lipid Metabolism of White and Brown Adipose Tissues in Obese Mice
}

\author{
Ra-Yeong Choi ${ }^{1}$ and Mi-Kyung Lee ${ }^{2, *}$ \\ 1 Department of Agricultural Biology, National Institute of Agricultural Sciences, Rural Development \\ Administration, Wanju 55365, Korea; fkdud1304@korea.kr \\ 2 Department of Food and Nutrition, Sunchon National University, Suncheon 57922, Korea \\ * Correspondence: leemk@scnu.ac.kr; Tel.: +82-61-750-3656; Fax: +82-61-750-3650
}

Citation: Choi, R.-Y.; Lee, M.-K. Polygonum multiflorum Thunb. Hot Water Extract Reverses High-Fat Diet-Induced Lipid Metabolism of White and Brown Adipose Tissues in Obese Mice. Plants 2021, 10, 1509 https://doi.org/10.3390/plants10081509

Academic Editor: Stefania Lamponi

Received: 7 June 2021

Accepted: 21 July 2021

Published: 23 July 2021

Publisher's Note: MDPI stays neutral with regard to jurisdictional claims in published maps and institutional affiliations.

Copyright: (c) 2021 by the authors. Licensee MDPI, Basel, Switzerland. This article is an open access article distributed under the terms and conditions of the Creative Commons Attribution (CC BY) license (https:// creativecommons.org/licenses/by/ $4.0 /)$.

\begin{abstract}
The purpose of the present study was to determine whether an anti-obesity effect of a Polygonum multiflorum Thunb. hot water extract (PW) was involved in the lipid metabolism of white adipose tissue (WAT) and brown adipose tissue (BAT) in high-fat diet (HFD)-induced C57BL/6N obese mice. Mice freely received a normal diet (NCD) or an HFD for 12 weeks; HFD-fed mice were orally given PW (100 or $300 \mathrm{mg} / \mathrm{kg}$ ) or garcinia cambogia (GC, $200 \mathrm{mg} / \mathrm{kg}$ ) once a day. After 12 weeks, PW (300 mg/kg) or GC significantly alleviated adiposity by reducing body weight, WAT weights, and food efficiency ratio. PW (300 mg/ kg) improved hyperinsulinemia and enhanced insulin sensitivity. In addition, PW (300 mg/kg) significantly down-regulated expression of carbohydrate-responsive element-binding protein (ChREBP) and diacylglycerol O-acyltransferase 2 (DGAT2) genes in WAT compared with the untreated HFD group. HFD increased BAT gene levels such as adrenoceptor beta 3 (ADRB3), peroxisome proliferator-activated receptor $\gamma(\operatorname{PPAR} \gamma)$, hormone-sensitive lipase (HSL), cluster of differentiation 36 (CD36), fatty acid-binding protein 4 (FABP4), PPAR $\gamma$ coactivator 1- $\alpha$ (PGC-1 $\alpha$ ), PPAR $\alpha$, and carnitine palmitoyltransferase 1B (CPT1B) compared with the NCD group; however, PW or GC effectively reversed those levels. These findings suggest that the anti-obesity activity of PW was mediated via suppression of lipogenesis in WAT, leading to the normalization of lipid metabolism in BAT.
\end{abstract}

Keywords: anti-obesity; Heshouwu; Polygonum multiflorum Thunb.; white adipose tissue; brown adipose tissue

\section{Introduction}

Obesity is a chronic complex disease caused by a persistent positive energy balance in which energy intake exceeds energy expenditure [1]. In mammals, adipose tissues are classified into three types: white adipose tissue (WAT), brown adipose tissue (BAT), or beige adipose tissue. WAT stores extra energy in a triglyceride (TG) form, while BAT is responsible for dissipation of energy as heat through thermogenesis to maintain body temperature and energy balance [2]. BAT activates thermogenesis in response to cold exposure and overfeeding, thereby contributing to the control of whole-body energy expenditure and body fat contents [3,4]. For this reason, activation of BAT is expected to provide a therapeutic effect on obesity and related metabolic disorders [5].

Polygonum multiflorum Thunb. (PM), called Heshouwu in China and East Asia, and Fo-ti in North America, is popular in clinical practice [6]. PM has been used to treat oxidative stress and age-related diseases in traditional medicine [7]. Pharmacological studies revealed that PM attenuates diabetes-induced osteoporosis [8], oxidative stressinduced liver injury [7], focal cerebral ischemia [9], and breast cancer [10], while promoting learning and memory ability [11]. PM possesses treatment effects on hyperlipidemia [12], non-alcoholic fatty liver disease (NAFLD) [13], and atherosclerosis [14]. Our previous study 
showed the anti-adiposity effects of a PM ethanol extract in 3T3-L1 adipocytes and high-fat diet (HFD)-induced obese mice [15]. In clinical application, PM is usually administrated as a water decoction containing hydrophilic components [16]. However, the possible role of a PM hot water extract (PW) in the lipid metabolic activities of WAT and BAT has never been reported. The present study examined the potential beneficial effects of PW in an HFD-induced obese animal model.

\section{Results}

\subsection{Effects of PW on Body Weight and Food Intake}

The average initial body weight of experimental groups was about $20 \mathrm{~g}$ (Table 1). After 7 weeks of HFD feeding, the body weight was significantly increased compared to that of the NCD group. However, the PW300 group showed a remarkable decrease of body weight compared with the HFD group after the 6-week experimental periods. The body weight gain in the HFD group was $16.00 \pm 0.61 \mathrm{~g}$ over the 12 -week study, whereas the PW300 and GC200 groups had markedly reduced total body weight gain, 19.9\% and 16.7\%, respectively, compared with the HFD group (Table 1). Food intake in the HFD group was significantly lower (12.7\%) than that of the NCD group (Table 2). PW and GC did not affect food intake, but the food efficiency ratios (FER) in the NCD, PW300, and GC200 groups were reduced compared with the HFD group (Table 2).

\subsection{Effects of PW on Relative Adipose Tissue Weight and Adipocyte Size}

All relative WAT weights, exclusive of mesenteric WAT, in the HFD group were significantly increased compared with those of the NCD group (Figure 1A,D). Conversely, the PW300 and GC200 groups tended to have lower weights of perirenal, subcutaneous, and interscapular WAT compared with those of the HFD group. Total WAT weights were significantly reduced by PW administration in a dose-dependent manner compared with the HFD group. No statistical significances were detected among the relative interscapular BAT weights of the groups (Figure 1B). The HFD group showed hypertrophy of the epididymal WAT, which was attenuated by treatment with PW and GC (Figure 1C). Moreover, the HFD group showed a larger adipocyte diameter in epididymal WAT, which was recovered following treatment with PW and GC (Figure 1E). Furthermore, the PW100, PW300, and GC200 groups had markedly reduced increases in HFD-induced fat size in the epididymal WAT, by 34.1, 33.2, and $12.8 \%$, respectively (Figure $1 \mathrm{~F}$ ).

Table 1. Effects of Polygonum multiflorum Thunb. hot water extract on body weight in HFD diet-induced obese mice.

\begin{tabular}{|c|c|c|c|c|c|}
\hline & NCD & HFD & PW100 & PW300 & GC200 \\
\hline \multicolumn{6}{|l|}{ Body weight (g) } \\
\hline 0 weeks & $20.26 \pm 0.23$ & $20.55 \pm 0.35$ & $20.18 \pm 0.24$ & $20.34 \pm 0.31$ & $20.39 \pm 0.31$ \\
\hline 1 weeks & $21.61 \pm 0.36$ & $22.50 \pm 0.36$ & $21.19 \pm 0.54$ & $20.96 \pm 0.42$ & $22.35 \pm 0.36$ \\
\hline 2 weeks & $22.46 \pm 0.41$ & $23.64 \pm 0.35$ & $22.30 \pm 0.45$ & $22.28 \pm 0.61$ & $24.03 \pm 0.27$ \\
\hline 3 weeks & $23.20 \pm 0.45$ & $24.67 \pm 0.32$ & $23.83 \pm 0.54$ & $23.52 \pm 0.54$ & $24.65 \pm 0.36$ \\
\hline 4 weeks & $24.30 \pm 0.56$ & $26.18 \pm 0.32$ & $24.75 \pm 0.50$ & $24.64 \pm 0.60$ & $26.28 \pm 0.48$ \\
\hline 5 weeks & $25.13 \pm 0.70$ & $27.06 \pm 0.42$ & $25.67 \pm 0.48$ & $24.90 \pm 0.65$ & $26.69 \pm 0.48$ \\
\hline 6 weeks & $26.53 \pm 0.75^{a b}$ & $28.84 \pm 0.44^{b}$ & $26.97 \pm 0.53^{a b}$ & $26.33 \pm 0.56^{\mathrm{a}}$ & $28.14 \pm 0.58^{a b}$ \\
\hline 7 weeks & $27.50 \pm 0.65^{\mathrm{a}}$ & $30.35 \pm 0.41^{c}$ & $28.20 \pm 0.55^{a b}$ & $27.92 \pm 0.50^{\mathrm{a}}$ & $30.06 \pm 0.38^{b c}$ \\
\hline 8 weeks & $27.70 \pm 0.91^{\mathrm{a}}$ & $31.35 \pm 0.49^{c}$ & $28.98 \pm 0.61^{\mathrm{abc}}$ & $28.10 \pm 0.55^{a b}$ & $30.23 \pm 0.42^{b c}$ \\
\hline 9 weeks & $28.65 \pm 0.97^{a}$ & $32.41 \pm 0.51^{b}$ & $30.14 \pm 0.76^{\mathrm{ab}}$ & $28.75 \pm 0.65^{\mathrm{a}}$ & $30.95 \pm 0.50 \mathrm{ab}$ \\
\hline 10 weeks & $30.22 \pm 0.91^{\mathrm{a}}$ & $34.45 \pm 0.54^{b}$ & $31.68 \pm 0.78^{a b}$ & $30.62 \pm 0.69^{a}$ & $32.10 \pm 0.59 \mathrm{ab}$ \\
\hline 11 weeks & $31.34 \pm 0.88^{\mathrm{a}}$ & $35.71 \pm 0.50^{b}$ & $33.39 \pm 0.76^{a b}$ & $32.04 \pm 0.85^{\mathrm{a}}$ & $33.09 \pm 0.63^{a b}$ \\
\hline 12 weeks & $31.85 \pm 0.89^{a}$ & $36.54 \pm 0.51^{b}$ & $34.42 \pm 0.83^{a b}$ & $33.16 \pm 0.77^{\mathrm{a}}$ & $33.73 \pm 0.57^{a b}$ \\
\hline Body weight gain (g) & $11.61 \pm 0.75^{\mathrm{a}}$ & $16.00 \pm 0.61^{b}$ & $14.23 \pm 0.63^{\mathrm{ab}}$ & $12.82 \pm 0.71^{\mathrm{a}}$ & $13.33 \pm 0.40^{\mathrm{a}}$ \\
\hline
\end{tabular}

Data are expressed as means \pm SE. Values with different superscript letters are significantly different at $p<0.05$ as determined by one-way ANOVA followed by Tukey's HSD test. 
Table 2. Effects of Polygonum multiflorum Thunb. hot water extract on food intake, food efficiency ratio, serum marker levels, and lipid contents in HFD diet-induced obese mice.

\begin{tabular}{|c|c|c|c|c|c|}
\hline & NCD & HFD & PW100 & PW300 & GC200 \\
\hline Food intake (g/day) & $3.24 \pm 0.05^{b}$ & $2.83 \pm 0.03^{a}$ & $2.73 \pm 0.02^{\mathrm{a}}$ & $2.72 \pm 0.03^{a}$ & $2.75 \pm 0.03^{a}$ \\
\hline FER & $0.0423 \pm 0.0022^{\mathrm{a}}$ & $0.0671 \pm 0.0021^{c}$ & $0.0619 \underset{\mathrm{bc}}{ \pm} 0.0025$ & $0.0558 \pm 0.0025^{b}$ & $0.0576 \pm 0.0013^{b}$ \\
\hline \multicolumn{6}{|l|}{ Serum marker levels } \\
\hline AST $(\mathrm{U} / \mathrm{L})$ & $54.62 \pm 2.92$ & $62.60 \pm 3.06$ & $62.00 \pm 3.86$ & $52.40 \pm 2.07$ & $54.87 \pm 2.96$ \\
\hline $\operatorname{ALT}(\mathrm{U} / \mathrm{L})$ & $23.12 \pm 2.01^{\mathrm{a}}$ & $34.40 \pm 2.70^{b}$ & $32.10 \pm 3.55^{\mathrm{ab}}$ & $24.50 \pm 2.12 \mathrm{ab}$ & $28.00 \pm 2.34 \mathrm{ab}$ \\
\hline Glucose (mmol/L) & $11.76 \pm 1.37$ & $12.95 \pm 0.73$ & $10.64 \pm 0.97$ & $11.07 \pm 1.01$ & $13.54 \pm 0.68$ \\
\hline Serum lipid contents & & & & & \\
\hline Triglyceride (mmol/L) & $0.80 \pm 0.05$ & $0.93 \pm 0.05$ & $0.94 \pm 0.03$ & $0.93 \pm 0.05$ & $0.83 \pm 0.02$ \\
\hline Free fatty acid (mmol/L) & $0.84 \pm 0.05^{b}$ & $0.79 \pm 0.07^{\mathrm{b}}$ & $0.76 \pm 0.03^{b}$ & $0.65 \pm 0.05^{a b}$ & $0.43 \pm 0.05^{\mathrm{a}}$ \\
\hline Total cholesterol (mmol/L) & $3.96 \pm 0.17$ & $4.60 \pm 0.16$ & $4.27 \pm 0.16$ & $4.13 \pm 0.09$ & $4.40 \pm 0.14$ \\
\hline HDL-cholesterol (mmol/L) & $2.56 \pm 0.05^{\mathrm{a}}$ & $3.01 \pm 0.10^{b}$ & $2.97 \pm 0.09 \mathrm{ab}$ & $2.90 \pm 0.05^{a b}$ & $3.21 \pm 0.19^{b}$ \\
\hline $\operatorname{HTR}(\%)$ & $65.38 \pm 2.52$ & $66.92 \pm 2.02$ & $69.79 \pm 1.52$ & $69.30 \pm 1.11$ & $74.62 \pm 4.61$ \\
\hline
\end{tabular}

Data are expressed as means \pm SE. Values with different superscript letters are significantly different at $p<0.05$ as determined by one-way ANOVA followed by Tukey's HSD test. Food efficiency ratio (FER) = body weight gain $(\mathrm{g} /$ day)/food intake (g/day). AST, aspartate aminotransferase; ALT, alanine aminotransferase. HTR = HDL-cholesterol/total cholesterol $\times 100$.

A

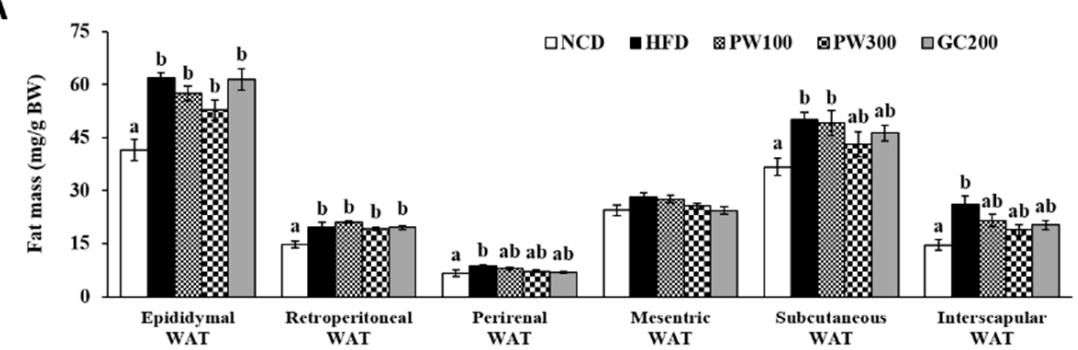

C

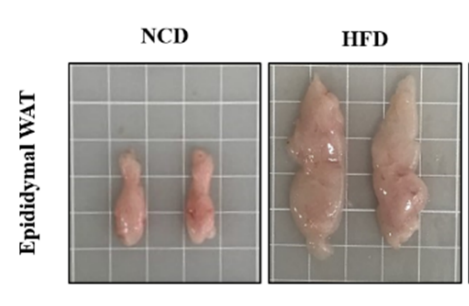

E

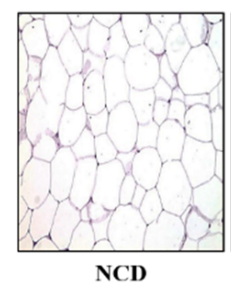

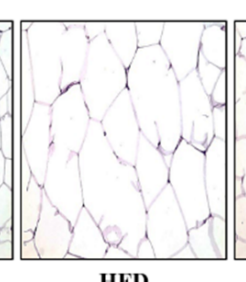

HFD
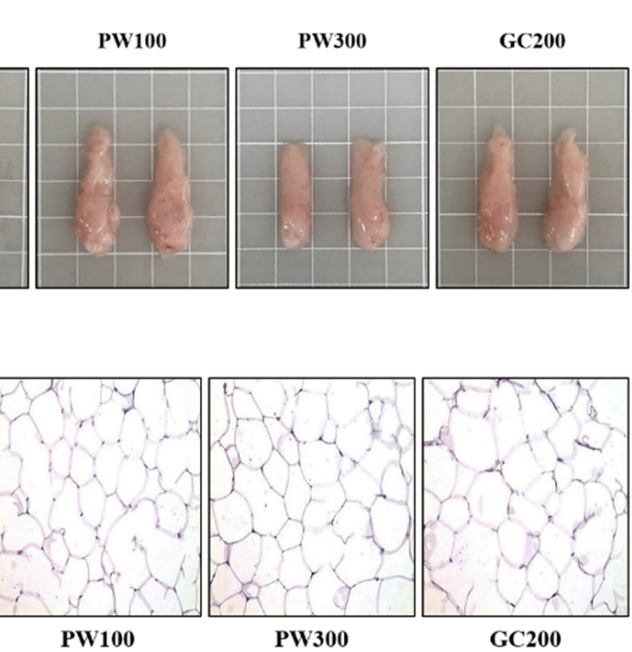

B
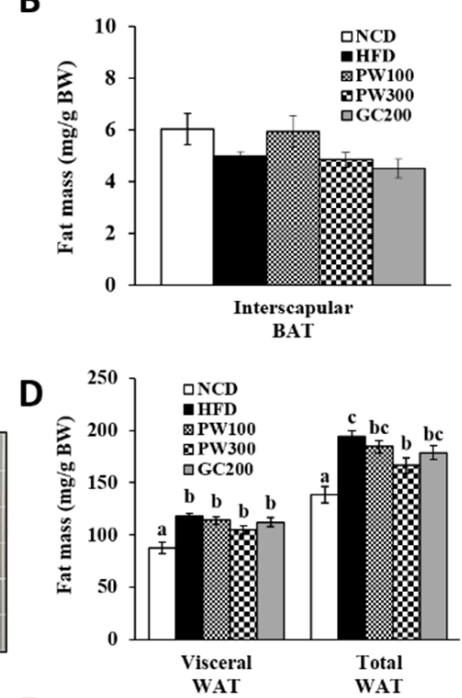

$\mathrm{F}$

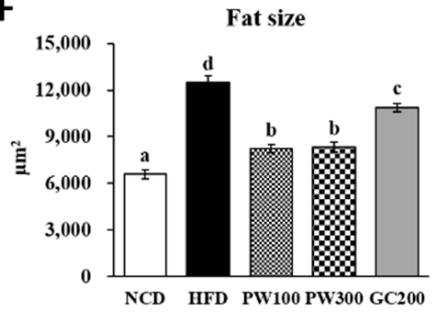

Figure 1. Effects of Polygonum multiflorum Thunb. hot water extract on WAT weights (A), BAT weight (B), representative photographs of epididymal WAT (C), visceral and total WAT weights (D), H\&E microscopic images of epididymal WAT (E), fat size of epididymal WAT (F) in HFD-induced obese mice. Data are expressed as means \pm SE. Values with different superscript letters are significantly different at $p<0.05$ as determined by one-way ANOVA followed by Tukey's HSD test. Magnifications $\times 200$. WAT, white adipose tissue; visceral WAT, the sum of epididymal WAT, retroperitoneal WAT, perirenal WAT, and mesenteric WAT; total WAT, the sum of visceral WAT, subcutaneous WAT, and interscapular WAT; BAT, brown adipose tissue. 


\subsection{Effects of PW on Lipid Metabolism and Inflammatory Gene Expression in Epididymal WAT}

No significant differences were observed in the expressions of peroxisome proliferatoractivated receptor $\gamma(P P A R \gamma)$, CCATT/enhancer-binding protein $\alpha(C / E B P \alpha)$, sterol regulatory element-binding protein $1 \mathrm{c}(S R E B P 1 c)$, fatty acid synthase (FAS), $P P A R \gamma$ coactivator $1-\alpha(P G C-1 \alpha)$, nuclear factor- $\mathrm{B} B(N F-\kappa B)$, tumor necrosis factor- $\alpha$ (TNF- $\alpha)$, and interleukin 6 (IL-6) genes in epididymal WAT among the groups (Figure 2A-D). The PW300 group had the lowest carbohydrate-responsive element-binding protein (ChREBP) mRNA expression, which was significantly down-regulated from that of the HFD group (Figure 2A). The diacylglycerol O-acyltransferase 2 (DGAT2) expression in HFD-fed mice was elevated compared with the NCD mice (Figure 2B). The PW300 and GC200 groups had significantly down-regulated DGAT2 expression, by $31.9 \%$ and $30.0 \%$, respectively, compared with that in the HFD group. Moreover, the PW100 and PW300 groups tended towards higher PPAR $\alpha$ gene expression compared with the HFD group (Figure 2C). Moreover, monocyte chemoattractant protein-1 (MCP-1) expression was notably up-regulated, by $63.1 \%$, in the HFD group compared with the NCD group; however, it had a tendency to down-regulate by $18.5 \%$ and $30.4 \%$, respectively, in the PW100 and PW300 group compared with the HFD group (Figure 2D).

A

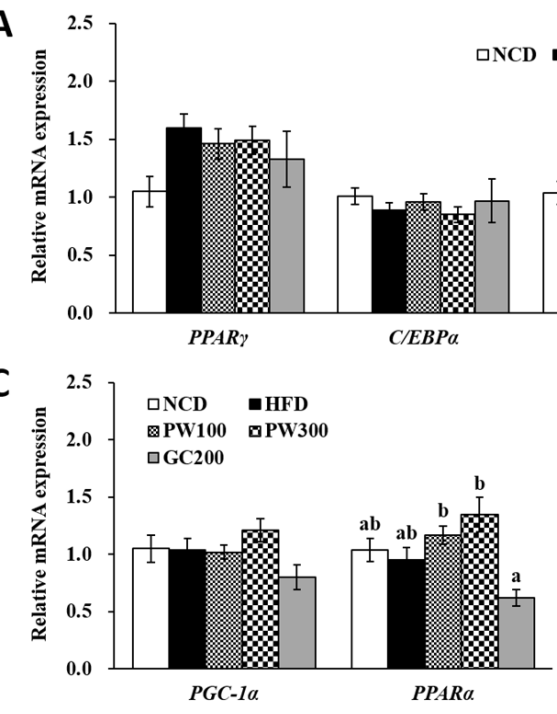

NCD $\square$ HFD $\circledast \mathrm{PW} 100 \square \mathrm{PW} 300 \square \mathrm{GC200}$

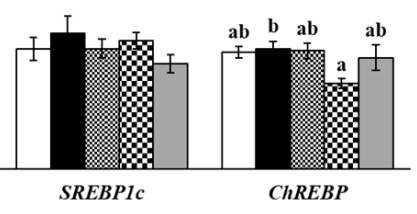

D $\quad 2.5$
B

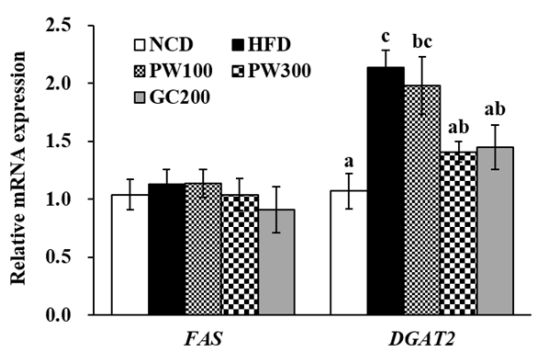

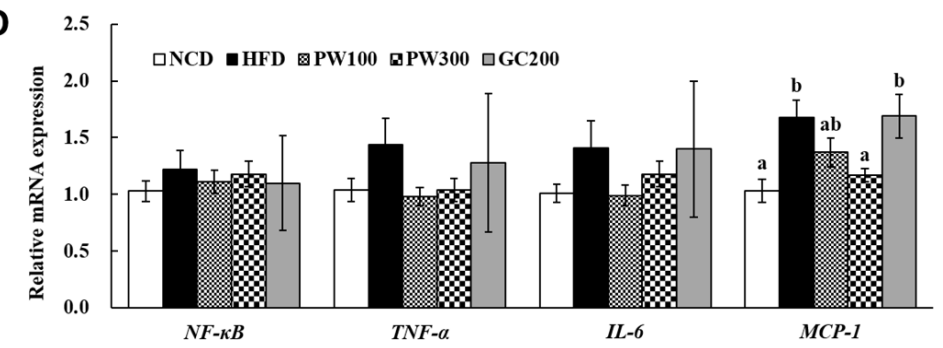

Figure 2. Effects of Polygonum multiflorum Thunb. hot water extract on adipogenic and lipogenic transcriptional factor (A), lipogenic genes (B), FA oxidative transcriptional factor (C), and inflammatory gene (D) expressions of epididymal WAT in HFD-induced obese mice. Data are expressed as means \pm SE. Values with different superscript letters are significantly different at $p<0.05$ as determined by one-way ANOVA followed by Tukey's HSD test.

\subsection{Effects of PW on Lipid Metabolism Gene Expression in Interscapular BAT}

As shown in Figures 3-5, the HFD group had elevated gene expression in interscapular BAT genes, such as adrenoceptor beta 3 (ADRB3), $P P A R \gamma$, hormone-sensitive lipase (HSL), cluster of differentiation 36 (CD36), fatty acid-binding protein 4 (FABP4), PGC-1 $\alpha, P P A R \alpha$, and carnitine palmitoyltransferase $1 \mathrm{~B}(C P T 1 B)$, and those elevated levels were recovered to that in the NCD group by treatment with PW (100 and $300 \mathrm{mg} / \mathrm{kg})$ or GC $(200 \mathrm{mg} / \mathrm{kg})$. The FAS mRNA level was slightly reduced, and the stearoyl-coenzyme A desaturase 1 (SCD1) mRNA level was significantly reduced in the HFD group compared to the NCD group. PW and GC did not affect these levels (Figure 4B). Furthermore, no changes were seen in uncoupling protein $1(U C P 1)$ and $C P T 2$ gene expressions among the groups (Figures $3 \mathrm{~A}$ and 5). 
A
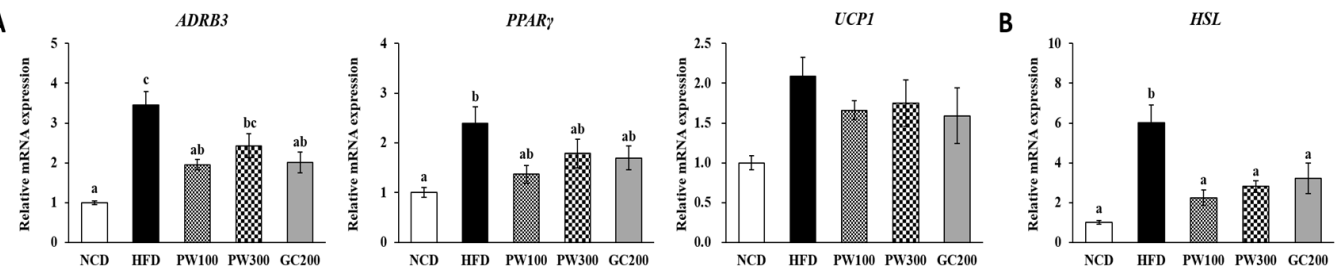

Figure 3. Effects of Polygonum multiflorum Thunb. hot water extract on thermogenic (A) and lipolytic (B) gene expressions in interscapular BAT in HFD-induced obese mice. Data are expressed as means \pm SE. Values with different superscript letters are significantly different at $p<0.05$ as determined by one-way ANOVA followed by Tukey's HSD test.

A

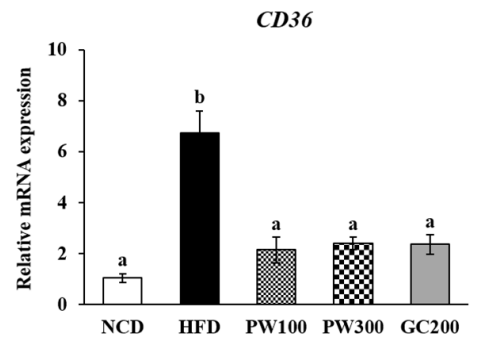

B

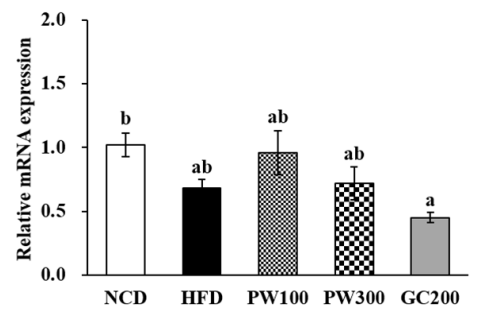

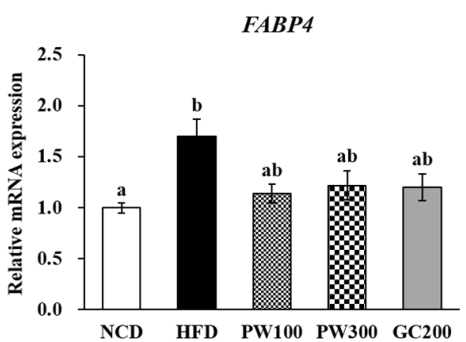

SCD1

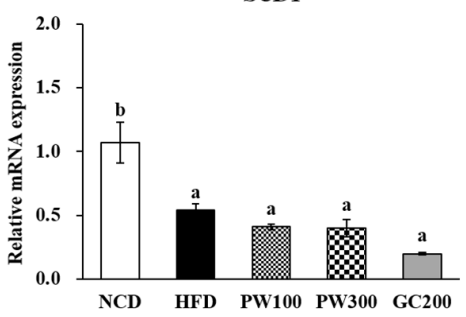

Figure 4. Effects of Polygonum multiflorum Thunb. hot water extract on FA uptake (A) and FA synthesis (B)-related gene expression in interscapular BAT in HFD-induced obese mice. Data are expressed as means \pm SE. Values with different superscript letters are significantly different at $p<0.05$ as determined by one-way ANOVA followed by Tukey's HSD test.
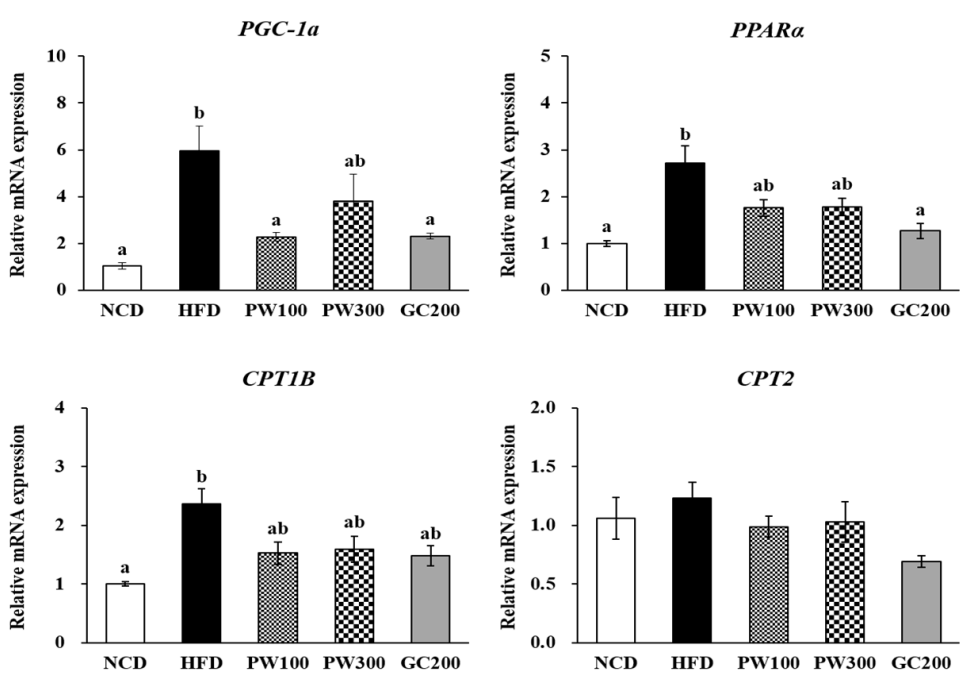

Figure 5. Effects of Polygonum multiflorum Thunb. hot water extract on FA oxidation-related gene expression in interscapular BAT in HFD-induced obese mice. Data are expressed as means \pm SE. Values with different superscript letters are significantly different at $p<0.05$ as determined by one-way ANOVA followed by Tukey's HSD test. 


\subsection{Effects of PW on Serum Biochemical Parameters and Lipid Profiles}

The serum alanine aminotransferase (ALT) level was significantly higher (1.48-fold) in the HFD group than that in the NCD group, whereas the serum ALT level was slightly decreased in the PW100, PW300, and GC200 groups by $6.7 \%, 28.8 \%$, and $18.6 \%$, respectively, compared to the HFD group (Table 2). No significant differences were observed in serum aspartate aminotransferase (AST) levels among the groups (Table 2). The serum FFA concentration was unaltered by the HFD, but it tended to decrease in the PW300 group compared to the HFD group and was suppressed in the GC200 group (Table 2). The serum HDL-cholesterol (HDL-C) level was 17.6\% higher in the HFD group compared with the NCD group (Table 2). No marked differences were detected in the serum TG and total cholesterol (TC) concentrations or the HDL-cholesterol (HDL-C) to TC ratio (HTR) among the groups (Table 2).

\subsection{Effects of PW on Hyperinsulinemia and Insulin Resistance}

Although there were no significant differences among the fasting serum glucose levels of the study groups (Table 2), the fasting serum insulin level and the homeostasis model assessment of insulin resistance (HOMA-IR) index were slightly elevated in the HFD group, approximately 1.5-fold that of the NCD group (Figure 6A,B). In contrast, treatment of the mice with PW $(300 \mathrm{mg} / \mathrm{kg})$ resulted in significant reductions in the insulin level and the HOMA-IR index, indicating improvements in hyperinsulinemia and insulin resistance were induced by the HFD.

A

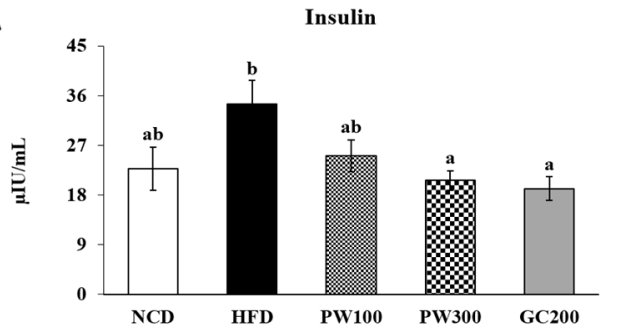

C

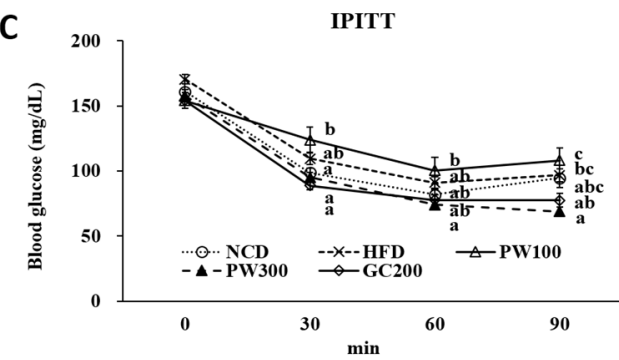

D

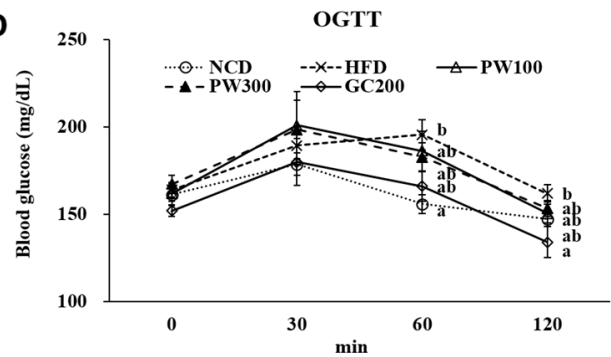

B
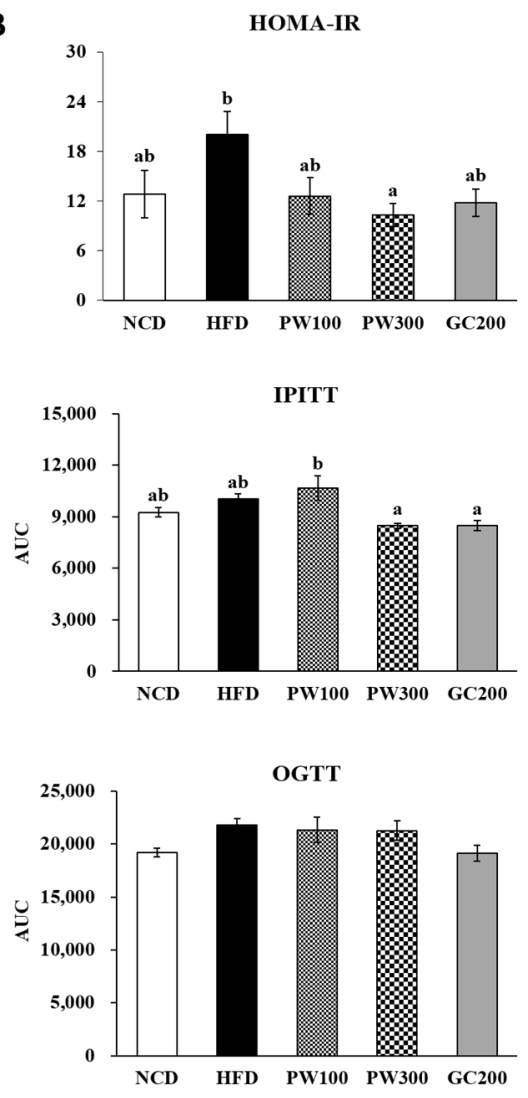

Figure 6. Effect of Polygonum multiflorum Thunb. hot water extract on serum insulin level (A), HOMA-IR index (B), IPITT (C), and OGTT (D) test in HFD-induced obese mice. Data are expressed as means $\pm \mathrm{SE}$. Values with different superscript letters are significantly different at $p<0.05$ as determined by one-way ANOVA followed by Tukey's HSD test. Homeostasis model assessment of insulin resistance $(\mathrm{HOMA}-\mathrm{IR})=$ fasting serum insulin $(\mu \mathrm{IU} / \mathrm{mL}) \times$ fasting serum glucose $(\mathrm{mmol} / \mathrm{L}) / 22.5$. IPITT, intraperitoneal insulin tolerance test; OGTT, oral glucose tolerance test. 
As shown Figure 6C, there were no changes in the initial blood glucose levels in all groups, but 30 and 90 min following the insulin injection, the HFD group tended to have an increased blood glucose level compared with that of the NCD group. However, the PW300 group exhibited a similar effect to that of the GC200 group and tended to decrease the blood glucose level compared with that of the HFD group. Especially, blood glucose at 90 min showed a significant down-regulation in the PW300 group. Indeed, both the PW300 and GC200 groups had slightly reduced intraperitoneal insulin tolerance test (IPITT) areas under the curve (AUCs) compared with that of the HFD group. An oral glucose tolerance test (OGTT) was performed at the end of the experiment (Figure 6D). The blood glucose level of the HFD group significantly was increased at $60 \mathrm{~min}$ after glucose loading and tended to increase at $120 \mathrm{~min}$. The PW100 and PW300 groups had slightly reduced fasting blood glucose levels at 60 and 120 min after glucose loading. Compared to the HFD group, the blood glucose level was significantly reduced in the GC200 group at $120 \mathrm{~min}$ in response to the glucose load. Thus, PW300 and GC enhanced insulin sensitivity in obese mice by improving IPITT.

\section{Discussion}

Obesity is considered a serious public health issues in countries around the world, and its control is actively being discussed [17]. Our previous study revealed that an ethanol extract of PM had anti-obesity effects in vitro and in vivo [15]. The ethanol extract of PM stimulated expression of lipolysis, fatty acid (FA) oxidation, and brown fat-specific genes in epididymal WAT of obese mice [15]. Based on the previous study's findings, this study aimed to explore whether the anti-obesity effects of PW were associated with its lipid molecular mechanism in WAT and/or BAT in HFD-induced obese mice.

The WAT anatomically consists two major adipose depots, subcutaneous WAT and visceral WAT [18]. An HFD results in an increase of whole-body fat and fat distribution, particularly fat deposition in visceral WAT $[19,20]$. Accumulation of visceral WAT is more closely associated with obesity-induced metabolic diseases than that of subcutaneous WAT [18]. A previous study showed that effective regulation of hypertrophy and hyperplasia in adipocytes expansion might be a potential therapeutic strategy for obesity [21]. In our study, PW and GC decreased the mean epididymal adipocyte size, indicating that PW and GC may directly affect a reduction in the size of adipocytes in WAT. In addition, food intake was reduced by the HFD with its high calorie density, but there was no significant change between the PW and GC administration. On the other hand, treatment with PW300 completely suppressed FER, total body weight gain, and WAT mass compared with those in the HFD group. FER is the body weight gain relative to the consumed food intake, and a low FER indicates that the body weight gain is small for the same amount of diet consumed. Consequently, the body weight loss effects of PW $(300 \mathrm{mg} / \mathrm{kg})$ are presumably due to the reductions of FER, total WAT mass, and epididymal WAT adipocyte size.

As an energy storage organ, WAT stores TG and releases FAs through lipogenesis and lipolysis, respectively [22]. Lipogenesis is a process that includes de novo FA synthesis and TG biosynthesis [22]. ChREBP is a metabolic regulator that modulates both lipid and glucose metabolism in adipose tissue [22-24], and ChREBP is mainly expressed in active sites of de novo lipogenesis such as liver, WAT, and BAT [25]. During the sequential esterification processes of FA, the DGAT2 enzyme catalyzes the last step of TG biosynthesis. In pharmacological studies, it has been established that inhibition of DGAT is a therapeutic approach to obesity and type 2 diabetes [26]. On the other hand, PPAR $\alpha$ controls expression of genes related to FA oxidation and exhibits hypolipidemic effects $[27,28]$. Some studies have indicated that PPAR $\alpha$ is expressed in the adipose tissue of humans and animals, indicating that adipose tissue might be a target organ of PPAR $\alpha$ activators [27,29-32]. In this study, we observed that GC treatment $(200 \mathrm{mg} / \mathrm{kg})$ only decreased DGAT2 expression, whereas PW treatment $(300 \mathrm{mg} / \mathrm{kg}$ ) significantly down-regulated ChREBP and DGAT2 expression and slightly up-regulated PPAR $\alpha$ expression in epididymal WAT, indicating partial mediation of reductions of adipocyte size and WAT mass. The WAT also secretes 
various adipokines for the control of whole-body energy homeostasis [18]. Obese WAT releases pro-inflammatory cytokines, including chemokines (e.g., MCP-1) [33]. A previous study showed that overexpression of MCP-1 in adipose tissue results in macrophage infiltration into adipose tissue, systemic insulin resistance, and fatty liver in obese mice [34]. The expressions of inflammatory genes $(N F-\kappa B, T N F-\alpha$, and $I L-6)$ following PW treatment (100 and $300 \mathrm{mg} / \mathrm{kg}$ ) tended to be lower than those in the HFD group, but the decreases were not statistically different. In addition, the PW100 and PW300 groups tended to decrease $M C P-1$ gene expression compared with that of the HFD group. Hence, the reduction of MCP-1 gene expression by PW treatment may have contributed to the prevention of obesity-induced inflammation.

Diet-induced thermogenesis occurs primarily in BAT and has a key role in regulating energy balance by burning off excess calories [35]. BAT contains UCP1, which uncouples energy substrate oxidation from mitochondrial ATP production, leading to the release of energy as heat [36]. BAT is activated in a UCP1-dependent manner and in the sympathetic nervous system (SNS) through ADRB3 [37,38]. Stimulation of SNS is driven by cold exposure, diet, stress, and inflammation, resulting in an increase in thermogenesis [37,38]. BAT uses FA and glucose as the main sources of energy for heat generation [4,39]. Activating ADRB3 enhances transcription of UCP1 and PGC- $1 \alpha$ and accelerates the activity of lipolytic enzymes, leading to the release of FAs that enter the mitochondria for $\beta$-oxidation [40]. Briefly, activation of BAT secretes FAs through phosphorylation of adipose TG lipase (ATGL) and HSL, and the released FA is converted to heat [39]. Moreover, lipoprotein lipase (LPL) hydrolyzes TG-rich lipoproteins in the bloodstream for FA uptake and transport [41]. The released FA is taken up by CD36 and FA transfer proteins and is transferred to the cytoplasm by FABP4, also known as adipocyte protein 2 (aP2) [41]. Sustained $\beta 3-$ adrenergic receptor stimulation increases de novo lipogenesis, eventually stored as TG in lipid droplets [40]. A previous study reported that mice fed an HFD over 2-4 weeks had significantly increased CPT2, acyl-CoA thioesterase 2 (ACOT2), and UCP1 levels compared with mice fed a low-fat diet, but the increased protein levels were not maintained and returned to basal levels in HFD-fed mice for 20 weeks [5]. Unlike the above results, Li et al. [42] reported that mice fed an HFD for 22 weeks activated the catabolism of FA and the compensatory energy expenditure through the increase of CPT2 and UCP1 in BAT. In our results, the HFD group had elevated expressions of ADRB3, PPAR $\gamma, H S L, C D 36, F A B P 4$, $P G C-1 \alpha, P P A R \alpha$, and $C P T 1 B$ genes in interscapular BAT. These results suggested that FA oxidation and lipolysis were up-regulated in response to fat overload. Interestingly, these gene expressions were restored by all of the tested concentrations of PW and GC. However, no significant changes were seen in the UCP1 and CPT2 gene expressions among the study groups. A recent study showed that an HFD stimulated FA $\beta$-oxidation by increasing CPT1B and CPT2 expressions, whereas metformin (a drug for the treatment of type 2 diabetes) significantly down-regulated the CPT1B and CPT2 expressions in BAT compared with HFD-fed mice, indicating that metformin might improve the energy metabolism of BAT and might reduce compensated energy expenditure [43]. As a result, the HFD-fed group exhibited blunt mitochondrial $\beta$-oxidation associated with a decrease in the ability to expend diet-derived energy as heat in response to a fat overload in BAT. The PW and GC treatment normalized diet-induced adaptive thermogenesis, and these changes were similar to a low dosage of PW $(100 \mathrm{mg} / \mathrm{kg})$ and GC $(200 \mathrm{mg} / \mathrm{kg})$. In the abnormal metabolic state, increased BAT gene expression via physiological compensation was recovered by PW and GC administration, potentially improving lipid metabolism.

An HFD can increase the TC serum level $[19,44,45]$. In this study, the PW300 group tended to have a reduced serum FFA level compared with that in the HFD group. Choi et al. [46] reported that, compared with a $0.5 \%$ PM ethanol extract intake, a 1\% PM ethanol extract intake significantly reduced serum TG and TC levels in high-cholesterol diet-fed rats. Clinically, elevations of serum AST and ALT levels have been considered biomarkers for NAFLD [47]. In the present study, levels of AST and ALT, which are mostly produced in hepatocytes, were measured in serum to evaluate the degree of hepatocyte damage. HFD-fed mice had 
significantly increased serum ALT, which was attenuated by PW (100 and $300 \mathrm{mg} / \mathrm{kg}$ ) and GC $(200 \mathrm{mg} / \mathrm{kg})$ treatments. A previous study demonstrated that oral administration of the aqueous extract of PM did not affect serum ALT and AST levels, even at a dosage of $40 \mathrm{~g} / \mathrm{kg}$ for 3 days in rats [48]. Based on the results of Jung et al. [49], the no observed adverse effect level (NOAEL) of PM in rats for 2 weeks was estimated to be $1000 \mathrm{mg} / \mathrm{kg}$. Our in vivo study also showed no symptoms of hepatotoxicity by PW treatment (100 and $300 \mathrm{mg} / \mathrm{kg}$ ) for 12 weeks. PM contains various antioxidant compounds, including polyphenolic compounds and flavonoids [16]. The total phenol $(85.43 \pm 4.46 \mathrm{mg}$ tannic acid equivalent (TE) $/ \mathrm{g}$ ) and flavonoid $(1.57 \pm 0.09 \mathrm{mg}$ rutin equivalent $(\mathrm{RE}) / \mathrm{g})$ contents of the PW used in this study were higher than those $(12.53 \pm 0.02 \mathrm{mg} / \mathrm{g}, 0.10 \pm 0.01 \mathrm{mg} / \mathrm{g}$, respectively) reported by Kim et al. [50]; however, total phenol and flavonoid contents of the water extract were lower than those in PM extracted by other solvents $(70 \% \mathrm{EtOH}>100 \%$ $\mathrm{EtOH}>$ distilled water). This is due to the higher polarity, compared to water, of other solvents used to extract phenolic compounds [51]. Noda et al. [52] showed that the PM hot water extract, which is the traditional and common PM preparation used for consumption, did not induce hepatotoxicity but did exhibit beneficial effects on liver function.

An HFD animal model could also be used to examine hyperinsulinemia and the development of insulin resistance [53-55]. Adipocytes may signal directly to beta cells to control insulin secretion and, therefore, could cause hyperinsulinemia regardless of blood glucose levels [56,57]. In this study, PW $(300 \mathrm{mg} / \mathrm{kg})$ and GC $(200 \mathrm{mg} / \mathrm{kg})$ treatments significantly reduced fasting serum insulin level without changing the fasting serum glucose level. Moreover, IPITT, which measures insulin sensitivity, was improved with PW $(300 \mathrm{mg} / \mathrm{kg})$ and GC $(200 \mathrm{mg} / \mathrm{kg})$ treatments. These data suggest that PW has the potential to protect against obesity-induced insulin resistance.

\section{Materials and Methods}

\subsection{Preparation of the PW Extract}

Extraction of PW was performed as previously described [58]. A previous study confirmed that PW contained 2,3,5,4'-tetrahydroxystilbene-2- $\beta$-glucoside, emodin, and physcion [58]. Briefly, the PM was obtained from Dong-Bu Herbal Marker (Suncheon, Korea). PM $(500 \mathrm{~g})$ was extracted repeatedly with water $(3 \times 5 \mathrm{~L})$ and exhaustive maceration at $85{ }^{\circ} \mathrm{C}$ for $3 \mathrm{~h}$. The supernatant was filtered and transferred into pre-weighed containers. The extract was concentrated by a rotary evaporator and then freeze-dried to obtain the crude extract (170 g).

\subsection{Animal Experiments}

Male C57BL/6N mice (4-week-old) were purchased from Orient Bio, Ltd. (Seoul, Korea). All mice were housed in individual cages under controlled temperature $\left(22 \pm 2{ }^{\circ} \mathrm{C}\right)$, humidity $(50 \pm 5 \%)$, and $12 \mathrm{~h}$ light-dark cycle conditions. After a one week adaptation period, the mice were randomly divided into five groups and received a normal diet (NCD, $n=9,10 \mathrm{kcal} \%$ fat, cat \#D10012G, Research Diets, Inc., New Brunswick, NJ, USA), HFD ( $n=11,45 \mathrm{kcal} \%$ fat, cat \#D12451, Research Diets, Inc.), HFD with oral administration of PW at $100 \mathrm{mg} / \mathrm{kg}$ body weight (PW100, $n=10$ ), HFD with PW at $300 \mathrm{mg} / \mathrm{kg}$ body weight (PW300, $n=10$ ), or HFD with garcinia cambogia (GC) at $200 \mathrm{mg} / \mathrm{kg}$ body weight (GC200, $n=8$, Shinwon, Anyang, Korea) for 12 weeks. GC is used a dietary supplement to reduce body fat and has major active ingredients, such as hydroxycitric acid [59]. Mice were provided experimental diet and tap water ad libitum. Body weight and food intake were measured weekly and every $2-3$ days, respectively, during the feeding period. FER was calculated using the following formula: body weight gain/food intake per day.

At the end of the 12-week treated period, mice were fasted for $12 \mathrm{~h}$, then anesthetized with ether and sacrificed. Blood samples were subsequently taken from the inferior vena cava for serum biomarker analysis. The epididymal, retroperitoneal, perirenal, mesenteric, subcutaneous, and interscapular WAT, and the interscapular BAT were excised immediately, rinsed with physiological saline, and weighed. All samples were stored at $-80^{\circ} \mathrm{C}$ until 
analysis. The experimental procedures were approved by the Sunchon National University Institutional Animal Care and Use Committee (SCNU IACUC-2017-04).

\subsection{Intraperitoneal Insulin Tolerance Test and Oral Glucose Tolerance Test}

IPITT and OGTT analyses were performed at 11 weeks and 12 weeks, respectively. For the IPITT, the mice were injected intraperitoneally with insulin ( $1 \mathrm{unit} / \mathrm{kg}$ body weight $)$ after $6 \mathrm{~h}$ of fasting. The fasting blood glucose levels were determined by using samples collected from the tail vein at $0,30,60$, and $90 \mathrm{~min}$ after the insulin injection. For the OGTT, the mice were fasted for $6 \mathrm{~h}$ and then given glucose orally ( $1 \mathrm{~g} / \mathrm{kg}$ body weight), and the fasting blood glucose levels were measured after $0,30,60$, and $120 \mathrm{~min}$.

\subsection{Serum Markers Levels and Lipid Contents}

Serum ALT and AST activities were measured using an automated chemistry analyzer (Fuji Dri-Chem 3500i, Fujifilm, Tokyo, Japan). Serum fasting glucose concentration was measured using a glucometer (G-doctor, AllMedicus, Co., Ltd., Anyang, Korea). Serum insulin level was determined by an ELISA kit (Morinaga Institute of Biological Science, Inc., Yokohama, Japan). The HOMA-IR was calculated as fasting serum insulin $(\mu \mathrm{IU} / \mathrm{mL}) \times$ fasting serum glucose (mmol/L)/22.5. The serum TC, HDL-C, TG (Asan Pharmaceutical Co., Ltd., Seoul, Korea), and FFA (Shinyang Diagnostics, Seoul, Korea) contents were measured using commercial kits. The HTR was calculated as HDL-C/TC $\times 100$.

\subsection{Histological Analysis}

Epididymal WAT was fixed with 10\% neutral-buffered formalin. The fixed tissues were paraffin-embedded, and 3-5 $\mu \mathrm{m}$ sections were prepared and stained with hematoxylin and eosin (H\&E). The stained area was then viewed using an optical microscope at $200 \times$ magnification.

\subsection{RNA Isolation and Quantitative Real-Time PCR ( $q R T-P C R)$ Analysis}

Total RNA was isolated from WAT and BAT using TRIzol reagent (Invitrogen, Carlsbad, CA, USA). RNA purity and integrity were evaluated using a Nanodrop 2000 spectrophotometer (Thermo Fisher Scientific, Waltham, MA, USA). The RNA was reverse transcribed into cDNA using a ReverTra Ace qPCR RT master mix (Toyobo, Osaka, Japan). qRT-PCR was performed using a SYBR green PCR kit (Qiagen, Hilden, Germany) and a CFX96TM real-time detection system (Bio-Rad Laboratories, Inc., Hercules, CA, USA). The primer sequences are shown in Table 3. The relative mRNA levels were measured by applying the $2^{-\triangle \triangle \mathrm{Ct}}$ method [60] and were normalized to the ribosomal protein lateral stalk subunit P0 (RPLP0) expression level in the same samples.

\subsection{Statistical Analysis}

Values are presented as means \pm standard error (SE) values. Statistical significance among groups were determined by one-way analysis of variance (ANOVA) and Tukey's HSD test using the Statistical Package for the Social Sciences (SPSS version 26, SPSS Inc., Chicago, IL, USA). A $p$-values less than 0.05 were considered as statistically significant. 
Table 3. Primer sequences for qRT-PCR.

\begin{tabular}{|c|c|c|}
\hline Gene & Full Name & Sequences of Forward and Reverse Primer $\left(5^{\prime}-3^{\prime}\right)$ \\
\hline$P G C-1 \alpha$ & Peroxisome proliferative activated receptor, gamma, coactivator 1 alpha & GTCATGTGACTGGGGACTGTAG/TCCACTCTGACACACAGCAC \\
\hline PPAR $\alpha$ & Peroxisome proliferator-activated receptor alpha & GCTGGAGGGTTCGTGGAGTC/CGGTGAGATACGCCCAAATGC \\
\hline UCP1 & Uncoupling protein 1 (mitochondrial, proton carrier) & CCTGCCTCTCTCGGAAACAA/TCTGGGCTTGCATTCTGACC \\
\hline CPT1B & Carnitine palmitoyltransferase $1 \mathrm{~b}$ & TGGCTACGGGGTCTCTTACA/AAGTTCGGCGATGTCCAACA \\
\hline CPT2 & Carnitine palmitoyltransferase 2 & GCCTGCTGTTGCGTGACTG/TGGTGGGTACGATGCTGTGC \\
\hline$H S L$ & Lipase, hormone sensitive & GTGAATGAGATGGCGAGGGTC/TGAGGAGTCGCGTTAGAGTC \\
\hline$P P A R \gamma$ & Peroxisome proliferator-activated receptor gamma & TCGCTGATGCACTGCCTATG/GAGAGGTCCACAGAGCTGAT \\
\hline$C / E B P \alpha$ & CCAAT/enhancer binding protein (C/EBP), alpha & GCGCAAGAGCCGAGATAAA/GGTGAGGACACAGACTCAAATC \\
\hline$A D R B 3$ & Adrenergic receptor, beta 3 & CAGGCTCTGTGTCTCTGGTTAG/GTGAGGAGACAGGGATGAAACC \\
\hline ChREBP & Carbohydrate-responsive element-binding protein & GAAGGAATGGGTCCAGACATAC/TCACACTGGTCACTCCTACA \\
\hline CD36 & CD36 antigen & GCTGTCAGGCGTCAGGATAA/TGGCTTCAGGGAGACTGTTG \\
\hline FABP4 & Fatty acid binding protein 4 , adipocyte & TTTGGTCACCATCCGGTCAG/CCCGCCATCTAGGGTTATGA \\
\hline FAS & Fatty acid synthase & TTGGAGCTAAGGCATGGTGG/GCAGTTGTCCTCTGGATGCT \\
\hline SCD1 & Stearoyl-coenzyme A desaturase 1 & TTCTTCATCGACTGCATGGC/ACTCAGAAGCCCAAAGCTCAG \\
\hline DGAT2 & Diacylglycerol O-acyltransferase 2 & CTGGCTGATAGCTGTGCTCTACTTC/TGCGATCTCCTGCCACCTTTC \\
\hline$N F-\kappa B$ & Nuclear factor of kappa light polypeptide gene enhancer in B cells & GAAGTGAGAGAGTGAGCGAGAGAG/CGGGTGGCGAAACCTCCTC \\
\hline$T N F-\alpha$ & Tumor necrosis factor & AAAGACACCATGAGCACAGAAAGC/GCCACAAGCAGGAATGAGAAGAG \\
\hline MCP1 & Chemokine (C-C motif) ligand 2 & GAAGGAATGGGTCCAGACATAC/TCACACTGGTCACTCCTACA \\
\hline RPLPO & Ribosomal protein, large, P0 & GCAGGTGTTTGACAACGGCAG/GATGATGGAGTGTGGCACCGA \\
\hline
\end{tabular}




\section{Conclusions}

In conclusion, PW (300 mg/ $\mathrm{kg}$ ) significantly ameliorated body weight gain, body fat, and insulin resistance in HFD-fed obese mice. These beneficial effects were accompanied by changes in lipid metabolism-related gene expressions in WAT and BAT. The PW treatment inhibited lipogenesis in WAT. Furthermore, PW normalized gene expressions related to HFD-induced adaptive thermogenesis in BAT. These results reveal that PW is a useful agent against obesity and obesity-associated metabolic diseases, and its effects are similar to those of GC.

Author Contributions: Conceptualization, R.-Y.C. and M.-K.L.; Methodology, R.-Y.C. and M.-K.L.; Validation, M.-K.L.; Investigation, R.-Y.C.; Data Curation, R.-Y.C.; Writing-Original Draft Preparation, R.-Y.C.; Writing-Review and Editing, M.-K.L.; Visualization, R.-Y.C.; Supervision, M.-K.L.; Project Administration, M.-K.L. All authors have read and agreed to the published version of the manuscript.

Funding: This work was supported by Suncheon Research Center for Natural Medicines.

Institutional Review Board Statement: The experimental procedures were approved by the Sunchon National University Institutional Animal Care and Use Committee (approval No. SCNU IACUC2017-04).

Informed Consent Statement: Not applicable.

Data Availability Statement: The data presented in this study are available on request from the corresponding author.

Conflicts of Interest: The authors declare no conflict of interest.

\section{References}

1. Mulya, A.; Kirwan, J.P. Brown and beige adipose tissue: Therapy for obesity and its comorbidities? Endocrinol. Metab. Clin. North. Am. 2016, 45, 605-621. [CrossRef] [PubMed]

2. Lee, J.H.; Park, A.; Oh, K.-J.; Lee, S.C.; Kim, W.K.; Bae, K.-H. The role of adipose tissue mitochondria: Regulation of mitochodrial function for the treatment of metabolic diseases. Int. J. Mol. Sci. 2019, 20, 4924. [CrossRef] [PubMed]

3. Sugita, J.; Yoneshiro, T.; Hatano, T.; Aita, S.; Ikemoto, T.; Uchiwa, H.; Iwanaga, T.; Kameya, T.; Kawai, Y.; Saito, M. Grains of paradise (Aframomum melegueta) extract activates brown adipose tissue and increases whole-body energy expenditure in men. $B r$. J. Nutr. 2013, 110, 733-738. [CrossRef]

4. Cannon, B.; Nedergaard, J. Brown adipose tissue: Function and physiological significance. Physiol. Rev. 2004, 84, 277-359. [CrossRef] [PubMed]

5. Ohtomo, T.; Ino, K.; Miyashita, R.; Chigira, M.; Nakamura, M.; Someya, K.; Inaba, N.; Fujita, M.; Takagi, M.; Yamada, J. Chronic high-fat feeding impairs adaptive induction of mitochondrial fatty acid combustion-associated proteins in brown adipose tissue of mice. Biochem. Biophys. Rep. 2017, 10, 32-38. [CrossRef]

6. Bounda, G.-A.; Feng, Y.U. Review of clinical studies of Polygonum multiflorum Thunb. and its isolated bioactive compounds. Pharmacogn. Res. 2015, 7, 225-236. [CrossRef]

7. Lin, E.-Y.; Chagnaadorj, A.; Huang, S.-J.; Wang, C.-C.; Chiang, Y.-H.; Cheng, C.-W. Hepatoprotective activity of the ethanolic extract of Polygonum multiflorum Thunb. against oxidative stress-induced liver injury. Evid. Based Complement. Alternat. Med. 2018, 2018, 4130307. [CrossRef]

8. Ham, J.R.; Lee, H.-I.; Choi, R.-Y.; Ryu, H.-S.; Yee, S.-T.; Kang, K.-Y.; Lee, M.-K. Heshouwu (Polygonum multiflorum Thunb.) extract attenuates bone loss in diabetic mice. Prev. Nutr. Food Sci. 2019, 24, 121-127. [CrossRef]

9. Chan, Y.-C.; Wang, M.-F.; Chen, Y.-C.; Yang, D.-Y.; Lee, M.-S.; Cheng, F.-C. Long-term administration of Polygonum multiflorum Thunb: Reduces cerebral ischemia-induced infarct volume in gerbils. Am. J. Chin. Med. 2003, 31, 71-77. [CrossRef]

10. Chen, H.-S.; Liu, Y.; Lin, L.-Q.; Zhao, J.-L.; Zhang, C.-P.; Jin, J.-C.; Wang, L.; Bai, M.-H.; Wang, Y.-C.; Liu, M.; et al. Anti-proliferative effect of an extract of the root of Polygonum multiflorum Thunb. on MCF-7 human breast cancer cells and the possible mechanisms. Mol. Med. Rep. 2011, 4, 1313-1319. [CrossRef]

11. Chan, Y.-C.; Cheng, F.-C.; Wang, M.-F. Beneficial effects of different Polygonum multiflorum Thunb. extracts on memory and hippocampus morphology. J. Nutr. Sci. Vitaminol. 2002, 48, 491-497. [CrossRef] [PubMed]

12. Xian, Z.; Liu, Y.; Xu, W.; Duan, F.; Guo, Z.; Xiao, H. The Anti-hyperlipidemia effects of raw Polygonum multiflorum extract in vivo. Biol. Pharm. Bull. 2017, 40, 1839-1845. [CrossRef]

13. Lin, P.; He, Y.R.; Lu, J.M.; Li, N.; Wang, W.G.; Gu, W.; Yu, J.; Zhao, R.H. In vivo lipid regulation mechanism of Polygoni multiflori radix in high-fat diet fed rats. Evid. Based Complement. Alternat. Med. 2014, 2014, 642058. [CrossRef] [PubMed] 
14. Yang, P.-Y.; Almofti, M.R.; Lu, L.; Kang, H.; Zhang, J.; Li, T.-J.; Rui, Y.-C.; Sun, L.-N.; Chen, W.-S. Reduction of atherosclerosis in cholesterol-fed rabbits and decrease of expressions of intracellular adhesion molecule-1 and vascular endothelial growth factor in foam cells by a water-soluble fraction of Polygonum multiflorum. J. Pharmacol. Sci. 2005, 99, 294-300. [CrossRef] [PubMed]

15. Choi, R.-Y.; Lee, H.-I.; Ham, J.R.; Yee, S.-T.; Kang, K.-Y.; Lee, M.-K. Heshouwu (Polygonum multiflorum Thunb.) ethanol extract suppresses pre-adipocytes differentiation in 3T3-L1 cells and adiposity in obese mice. Biomed. Pharmacother. 2018, 106, 355-362 [CrossRef]

16. Wei, Y.; Liu, M.; Liu, J.; Li, H. Influence factors on the hepatotoxicity of Polygoni Multiflori Radix. Evid. Based Complement. Altern. Med. 2019, 2019, 5482896. [CrossRef]

17. Li, T.; Gong, H.; Yuan, Q.; Du, M.; Ren, F.; Mao, X. Supplementation of polar lipids-enriched milk fat globule membrane in high-fat diet-fed rats during pregnancy and lactation promotes brown/beige adipocyte development and prevents obesity in male offspring. FASEB J. 2020, 34, 4619-4634. [CrossRef] [PubMed]

18. Choe, S.S.; Huh, J.Y.; Hwang, I.J.; Kim, J.I.; Kim, J.B. Adipose tissue remodeling: Its role in energy metabolism and metabolic disorders. Front. Endocrinol. 2016, 7, 30. [CrossRef]

19. Park, Y.-J.; Lee, G.-S.; Cheon, S.-Y.; Cha, Y.-Y.; An, H.-J. The anti-obesity effects of Tongbi-san in a high-fat diet-induced obese mouse model. BMC Complement. Altern. Med. 2019, 19, 1. [CrossRef]

20. Yuan, H.; Chung, S.; Ma, Q.; Ye, L.I.; Piao, G. Combination of deep sea water and Sesamum indicum leaf extract prevents high-fat diet-induced obesity through AMPK activation in visceral adipose tissue. Exp. Ther. Med. 2016, 11, 338-344. [CrossRef]

21. Lu, Y.A.; Lee, H.G.; Li, X.; Hyun, J.-M.; Kim, H.-S.; Kim, T.H.; Kim, H.-M.; Lee, J.J.; Kang, M.-C.; Jeon, Y.-J. Anti-obesity effects of red seaweed, Plocamium telfairiae, in C57BL/ 6 mice fed a high-fat diet. Food Funct. 2020, 11, 2299-2308. [CrossRef]

22. Luo, L.; Liu, M. Adipose tissue in control of metabolism. J. Endocrinol. 2016, 231, R77-R99. [CrossRef]

23. Herman, M.A.; Peroni, O.D.; Villoria, J.; Schön, M.R.; Abumrad, N.A.; Blüher, M.; Klein, S.; Kahn, B.B. A novel ChREBP isoform in adipose tissue regulates systemic glucose metabolism. Nat. Cell Biol. 2012, 484, 333-338. [CrossRef]

24. Eissing, L.; Scherer, T.; Tödter, K.; Knippschild, U.; Greve, J.W.; Buurman, W.A.; Pinnschmidt, H.O.; Rensen, S.S.; Wolf, A.M.; Bartelt, A.; et al. De novo lipogenesis in human fat and liver is linked to ChREBP- $\beta$ and metabolic health. Nat. Commun. 2013, 4, 1528. [CrossRef]

25. Ortega-Prieto, P.; Postic, C. Carbohydrate sensing through the transcription factor ChREBP. Front. Genet. 2019, 10, 472. [CrossRef]

26. Wang, W.; He, Y.; Lin, P.; Li, Y.; Sun, R.; Gu, W.; Yu, J.; Zhao, R. In vitro effects of active components of Polygonum Multiflorum Radix on enzymes involved in the lipid metabolism. J. Ethnopharmacol. 2014, 153, 763-770. [CrossRef] [PubMed]

27. Goto, T.; Lee, J.; Teraminami, A.; Kim, Y.; Hirai, S.; Uemura, T.; Inoue, H.; Takahashi, N.; Kawada, T. Activation of peroxisome proliferator-activated receptor-alpha stimulates both differentiation and fatty acid oxidation in adipocytes. J. Lipid Res. 2011, 52, 873-884. [CrossRef] [PubMed]

28. Lefebvre, P.; Chinetti, G.; Fruchart, J.; Staels, B. Sorting out the roles of PPAR $\alpha$ in energy metabolism and vascular homeostasis. J. Clin. Invest. 2006, 116, 571-580. [CrossRef]

29. Tsuchida, A.; Yamauchi, T.; Takekawa, S.; Hada, Y.; Ito, Y.; Maki, T.; Kadowaki, T. Peroxisome proliferator-activated receptor $(\mathrm{PPAR}) \alpha$ activation increases adiponectin receptors and reduces obesity-related inflammation in adipose tissue: Comparison of activation of PPAR $\alpha, \operatorname{PPAR} \gamma$, and their combination. Diabetes 2005, 54, 3358-3370. [CrossRef] [PubMed]

30. Hiuge, A.; Tenenbaum, A.; Maeda, N.; Benderly, M.; Kumada, M.; Fisman, E.Z.; Tanne, D.; Matas, Z.; Hibuse, T.; Fujita, K.; et al. Effects of peroxisome proliferator-activated receptor ligands, bezafibrate and fenofibrate, on adiponectin level. Arterioscler. Thromb. Vasc. Biol. 2007, 27, 635-641. [CrossRef] [PubMed]

31. Loviscach, M.; Rehman, N.; Carter, L.; Mudaliar, S.; Mohadeen, P.; Ciaraldi, T.P.; Veerkamp, J.H.; Henry, R.R. Distribution of peroxisome proliferator-activated receptors (PPARs) in human skeletal muscle and adipose tissue: Relation to insulin action Diabetologia 2000, 43, 304-311. [CrossRef]

32. Guzmán, M.; Verme, J.L.; Fu, J.; Oveisi, F.; Blázquez, C.; Piomelli, D. Oleoylethanolamide stimulates lipolysis by activating the nuclear receptor peroxisome proliferator-activated receptor $\alpha$ (PPAR- $\alpha$ ). J. Biol. Chem. 2004, 279, 27849-27854. [CrossRef] [PubMed]

33. Villarroya, F.; Cereijo, R.; Gavaldà-Navarro, A.; Villarroya, J.; Giralt, M. Inflammation of brown/beige adipose tissues in obesity and metabolic disease. J. Intern. Med. 2018, 284, 492-504. [CrossRef] [PubMed]

34. Kanda, H.; Tateya, S.; Tamori, Y.; Kotani, K.; Hiasa, K.-I.; Kitazawa, R.; Kitazawa, S.; Miyachi, H.; Maeda, S.; Egashira, K.; et al. MCP-1 contributes to macrophage infiltration into adipose tissue, insulin resistance, and hepatic steatosis in obesity. J. Clin. Investig. 2006, 116, 1494-1505. [CrossRef] [PubMed]

35. Jun, H.-J.; Joshi, Y.; Patil, Y.; Noland, R.C.; Chang, J.S. NT-PGC-1 $\alpha$ activation attenuates high-fat diet-induced obesity by enhancing brown fat thermogenesis and adipose tissue oxidative metabolism. Diabetes 2014, 63, 3615-3625. [CrossRef] [PubMed]

36. Argyropoulos, G.; Harper, M.-E. Invited review: Uncoupling proteins and thermoregulation. J. Appl. Physiol. 2002, 92, 2187-2198. [CrossRef]

37. Hibi, M.; Oishi, S.; Matsushita, M.; Yoneshiro, T.; Yamaguchi, T.; Usui, C.; Yasunaga, K.; Katsuragi, Y.; Kubota, K.; Tanaka, S.; et al. Brown adipose tissue is involved in diet-induced thermogenesis and whole-body fat utilization in healthy humans. Int. J. Obes. 2016, 40, 1655-1661. [CrossRef] 
38. Chernogubova, E.; Hutchinson, D.S.; Nedergaard, J.; Bengtsson, T. $\alpha 1$ - and $\beta 1$-Adrenoceptor signaling fully compensates for $\beta 3$-adrenoceptor deficiency in brown adipocyte norepinephrine-stimulated glucose uptake. Endocrinology 2005, 146, 2271-2284. [CrossRef]

39. Lee, H.J. Exercise and activation of brown adipose tissue. Asian J. Kinesiol. 2018, 20, 1-11. [CrossRef]

40. Hoeke, G.; Kooijman, S.; Boon, M.R.; Rensen, P.C.; Berbée, J.F. Role of brown fat in lipoprotein metabolism and atherosclerosis. Circ. Res. 2016, 118, 173-182. [CrossRef] [PubMed]

41. Calderon-Dominguez, M.; Mir, J.F.; Fucho, R.; Weber, M.; Serra, D.; Herrero, L. Fatty acid metabolism and the basis of brown adipose tissue function. Adipocyte 2016, 5, 98-118. [CrossRef] [PubMed]

42. Li, J.; Zhao, W.G.; Shen, Z.F.; Yuan, T.; Liu, S.N.; Liu, Q.; Fu, Y.; Sun, W. Comparative proteome analysis of brown adipose tissue in obese C57BL/6J mice using iTRAQ-coupled 2D LC-MS/MS. PLoS ONE 2015, 10, e0119350. [CrossRef] [PubMed]

43. Yuan, T.; Li, J.; Zhao, W.-G.; Sun, W.; Liu, S.-N.; Liu, Q.; Fu, Y.; Shen, Z.-F. Effects of metformin on metabolism of white and brown adipose tissue in obese C57BL/6J mice. Diabetol. Metab. Syndr. 2019, 11, 96. [CrossRef] [PubMed]

44. Lee, H.; Ahn, J.; Shin, S.S.; Yoon, M. Ascorbic acid inhibits visceral obesity and nonalcoholic fatty liver disease by activating peroxisome proliferator-activated receptor $\alpha$ in high-fat-diet-fed C57BL/6J mice. Int. J. Obes. 2019, 43, 1620-1630. [CrossRef] [PubMed]

45. Cui, C.; Li, Y.; Gao, H.; Zhang, H.; Han, J.; Zhang, D.; Li, Y.; Zhou, J.; Lu, C.; Su, X. Modulation of the gut microbiota by the mixture of fish oil and krill oil in high-fat diet-induced obesity mice. PLoS ONE 2017, 12, e0186216. [CrossRef]

46. Choi, J.-H.; Lee, H.-S.; Kim, Y.-E.; Kim, B.-M.; Kim, I.-H.; Lee, C.-H. Effect of Polygonum multiflorum Thunberg extract on lipid metabolism in rats fed high-cholesterol diet. J. Korean Soc. Food Sci. Nutr. 2012, 41, 957-962. [CrossRef]

47. Zheng, S.; Hoos, L.; Cook, J.; Tetzloff, G.; Davis, H., Jr.; van Heek, M.; Hwa, J.J. Ezetimibe improves high fat and cholesterol diet-induced non-alcoholic fatty liver disease in mice. Eur. J. Pharmacol. 2008, 584, 118-124. [CrossRef]

48. Li, D.-K.; Chen, J.; Ge, Z.-Z.; Sun, Z.-X. Hepatotoxicity in rats induced by aqueous extract of Polygoni Multiflori Radix, root of Polygonum multiflorum related to the activity inhibition of CYP1A2 or CYP2E1. Evid. Based Complement. Altern. Med. 2017, 2017, 9456785. [CrossRef] [PubMed]

49. Jung, S.; Son, H.; Hwang, C.; Cho, K.; Park, S.; Kim, H.; Kim, H.J. The Root of Polygonum multiflorum Thunb. alleviates non-alcoholic steatosis and insulin resistance in high fat diet-fed mice. Nutrients 2020, 12, 2353. [CrossRef]

50. Kim, E.-S.; Kwon, H.-J. Development of Korean herbal medicine cosmetics containing Polygonum multiflorum extracts. Med. Leg. Update 2019, 19, 388. [CrossRef]

51. Ezez, D.; Tefera, M. Effects of solvents on total phenolic content and antioxidant activity of ginger extracts. J. Chem. 2021, 2021, 6635199. [CrossRef]

52. Noda, T.; Yamada, T.; Ohkubo, T.; Omura, T.; Ono, T.; Adachi, T.; Awaya, T.; Tasaki, Y.; Shimizu, K.; Matsubara, K. Hot-waterextracts of Polygonum multiflorum do not induce any toxicity but elicit limited beneficial effects on the liver in mice. J. Health Sci. 2009, 55, 720-725. [CrossRef]

53. Hariri, N.; Thibault, L. High-fat diet-induced obesity in animal models. Nutr. Res. Rev. 2010, 23, 270-299. [CrossRef] [PubMed]

54. Woods, S.C.; Seeley, R.; Rushing, P.A.; D'Alessio, D.; Tso, P. A Controlled high-fat diet induces an obese syndrome in rats. J. Nutr. 2003, 133, 1081-1087. [CrossRef]

55. Woods, S.C.; D’Alessio, D.A.; Tso, P.; Rushing, P.A.; Clegg, D.J.; Benoit, S.C.; Gotoh, K.; Liu, M.; Seeley, R.J. Consumption of a high-fat diet alters the homeostatic regulation of energy balance. Physiol. Behav. 2004, 83, 573-578. [CrossRef]

56. Czech, M.P. Insulin action and resistance in obesity and type 2 diabetes. Nat. Med. 2017, 23, 804-814. [CrossRef]

57. Lo, J.C.; Ljubicic, S.; Leibiger, B.; Kern, M.; Leibiger, I.B.; Moede, T.; Kelly, M.E.; Bhowmick, D.C.; Murano, I.; Cohen, P.; et al. Adipsin is an adipokine that improves $\beta$ cell function in diabetes. Cell 2014, 158, 41-53. [CrossRef]

58. Hwang, Y.H.; Kang, K.Y.; Kim, J.J.; Lee, S.J.; Son, Y.J.; Paik, S.H.; Yee, S.T. Effects of hot water extracts from Polygonum multiflorum on ovariectomy induced osteopenia in mice. Evid. Based Complement. Alternat. Med. 2016, 2016, 8970585. [CrossRef]

59. Maia-Landim, A.; Lancho, C.; Poblador, M.S.; Lancho, J.L.; Ramírez, J.M. Garcinia cambogia and Glucomannan reduce weight, change body composition and ameliorate lipid and glucose blood profiles in overweight/obese patients. J. Herb. Med. 2021, 26, 100424. [CrossRef]

60. Livak, K.J.; Schmittgen, T.D. Analysis of relative gene expression data using real-time quantitative PCR and the $2^{-\Delta \Delta C t}$ method. Methods 2001, 25, 402-408. [CrossRef] 